\title{
Geochemistry and mineralogy of arsenic trioxide dust from the Giant Mine, Yellowknife, Canada
}

\author{
JULLIETA E. LUM ${ }^{1 *}$, JOYCE M. MCBETH ${ }^{1}$, HEATHER E. \\ JAMIESON $^{2}$, AND MATTHEW B. J. LINDSAY ${ }^{1}$ \\ ${ }^{1}$ Department of Geological Sciences, University of \\ Saskatchewan, Saskatoon, SK, Canada \\ (*jullieta.1um@usask.ca, joyce.mcbeth@usask.ca, \\ matt.lindsay@usask.ca) \\ ${ }^{2}$ Department of Geological Sciences and Geological \\ Engineering, Queens University, Kingston, ON, Canada \\ (jamieson2@queensu.ca)
}

Mining and processing of gold-bearing arsenopyrite ore in the Yellowknife, Canada area (1949-1999) generated $c a$. 237,000 tonnes of $\mathrm{As}_{2} \mathrm{O}_{3}$ roaster dust stored in underground chambers. Although knowledge of the geochemistry and mineralogy of this dust is essential for long-term management and remediation, current understanding is limited. In this study, we examined dust samples collected from nine underground storage chambers at the Giant Mine to constrain compositional heterogeneity and solid-phase $\mathrm{As}$ and $\mathrm{Sb}$ speciation.

ICP and XRF analyses indicated elevated As (> 60\%) with a wide range of $\mathrm{Fe}, \mathrm{Sb}, \mathrm{S}, \mathrm{Al}, \mathrm{K}$ and $\mathrm{Pb}$ contents. More subtle variations are observed in the contents of $\mathrm{Mg}, \mathrm{Ca}, \mathrm{Na}$ and $\mathrm{Cu}$. XRD and SEM-EDX data reveal that the dust is dominated by crystalline arsenolite $\left(\mathrm{As}_{2} \mathrm{O}_{3}\right)$, with minor to accessory quartz, gypsum, calcite, dolomite, chalcopyrite and magnesioferrite. The majority of As (and $\mathrm{Sb}$ ) is hosted by arsenolite, with some As present in pyrite, Fe-oxides (magnetite, hematite) and secondary phases (tentatively scorodite, arseniosiderite and yukonite).

Analyses of XANES spectra indicate that As is present primarily as $\mathrm{As}(\mathrm{III})$ with varying proportions of $\mathrm{As}(\mathrm{V}), \mathrm{As}(\mathrm{II})$ and As(-I). EXAFS modeling resullts are consistent with the local structure of arsenolite. Using the bulk mineralogy and geochemistry, we traced structural changes in the samples and explored the effects of $\mathrm{Sb}$ occupancy in the first coordination sphere of As for the fitted spectra. We further analysed the EXAFS spectra for possible S- and Fe-bonded complexes from additional arsenic-bearing phases.

This study improves current knowledge of chemical heterogeneity within the chambers and provides understanding of the speciation and molecular structure of As in the dust, needed to evaluate the stability of As and potential for mobilization during long-term management. 